\title{
Two-Switch High Gain Non-Isolated Cuk Converter
}

\author{
Yasser Almalaq \\ Electrical Engineering Department \\ University of Hail \\ Hail, Saudi Arabia \\ yasseram1107@hotmail.com
}

\author{
Mohammad Matin \\ Department of Electrical \& Computer Engineering \\ University of Denver \\ Denver, USA \\ mohammad.matin@du.edu
}

\begin{abstract}
This paper introduces a two-switch high gain nonisolated Cuk converter which can be used as a high gain DC-DC converter in renewable energy, such as photovoltaic and fuel cell, applications because their output is low. As the conventional, the proposed Cuk converter provides negative output voltage but with a higher voltage in magnitude. The main advantage of the proposed converter is having lower voltage stress with the ability to maintain a higher voltage gain. By combining a switchedinductor and a switched-capacitor into the conventional $\mathrm{Cuk}$ converter, the proposed Cuk converter has the ability to reach $\mathbf{1 3}$ times the input voltage for a duty cycle $D$ of 0.75 . Also, by attaching more switched-inductors to the proposed Cuk converter, more voltage gain can be achieved. A complete theoretical analysis of the Continuous Conduction Mode (CCM) of the proposed $\mathrm{Cuk}$ converter is presented and the key aspects of the circuit design have been derived. Also, a comparison in terms of voltage gain and voltage stress between the proposed Cuk converter and Cuk converters using other techniques is presented. The proposed Cuk converter has been designed for $100 \mathrm{~W}$ rated power, $-152 \mathrm{~V}$ output voltage, $50 \mathrm{kHz}$ switching frequency, and $75 \%$ duty cycle. The presented converter is simulated in Matlab/Simulink and the results are discussed.
\end{abstract}

Keywords-Cuk converter; DC-DC converters; photovoltaic; switched-inductor; switched-capacitor

\section{INTRODUCTION}

Due to the expected depletion of the traditional energy sources, the world pays growing attention to alternative ones [1]. Nowadays, most attention goes to the photovoltaic (PV) energy source because it is a pollution free, stable system, and has continuous reduction in cost [2]. The price of a PV panel went from $\$ 4.90 / \mathrm{WPK}$ in 1998 down to $\$ 1.28 / \mathrm{WPK}$ in 2011 which means $74 \%$ reduction. PV systems are used today in many applications, such as water pumping, battery charging, home power supply, etc. [3-5]. Figure 1 shows a block diagram of a typical sustainable energy system, which is composed of renewable energy sources, a high step-up DC-DC converter, a DC grid, and an inverter for AC applications. Usually, the rated voltage of renewable energy sources, such as PV and fuel cell, is at low level, and thus, a high gain DC-DC converter is required. Generally, the most commonly used topology to supply high output voltage is the conventional boost converter. However, when the conventional boost converter is operated at a high output voltage, the duty cycle will become unity. This will lead to induce high current ripple, low efficiency, and result in severe reverse-recovery as well as high Electro
Magnetic Interference (EMI) problems [6-8]. Many high stepup DC-DC converters have been proposed and are utilized in renewable energy applications [9-16].

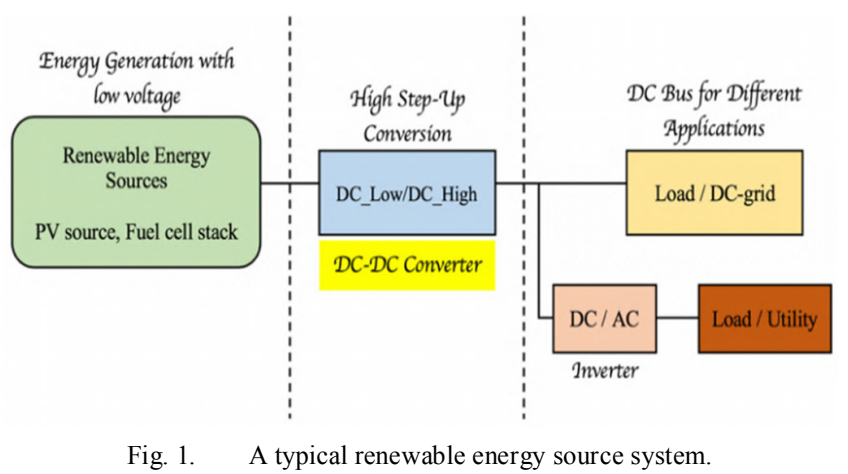

In this paper, the main aim was to design a DC-DC converter with high voltage gain and low voltage stress on the main semiconductor switch. This was done by integrating both the switched-inductor and the switched-capacitor techniques into the conventional Cuk converter. The Cuk converter has many advantages over other non-isolated converters, such as having non-pulsating input and output currents, low output voltage ripple, and good steady-state performance [17-19].

\section{POWER CIRCUIT}

A MOSFET, a diode, a capacitor, and an inductor have been added to the conventional Cuk converter to maintain high voltage gain and low voltage stress in order to form the proposed Cuk converter as shown in Figure 2. A MOSFET and an inductor are added to form the switched-inductor in which the two inductors are charged in parallel when the two MOSFETs are on, and they get discharged in series when the two MOSFETs are off. Moreover, the diode and the capacitor are added to perform the switched-capacitor in which the two capacitors are discharged in series when the two MOSFETs are on, and they get charged in parallel when the two MOSFETs are off.

\section{MODES OF OPERATION}

The proposed Cuk converter is analyzed in Continuous Conduction Mode (CCM). The operation of the proposed converter is that either both the MOSFETs are simultaneously on or off. Thus, two modes of operation exist. 


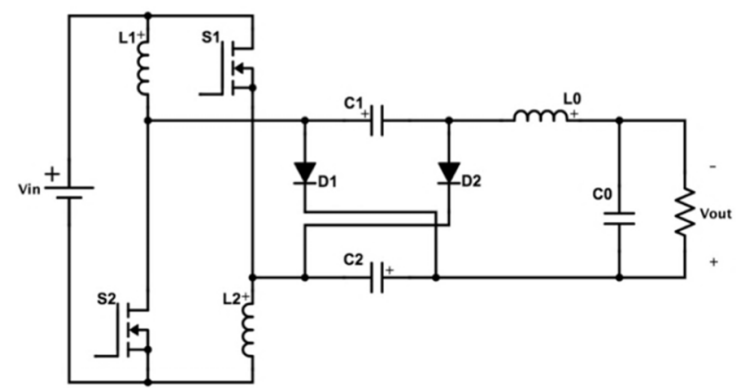

Fig. 2. The proposed Cuk converter.

\section{A. On-Mode}

When the two MOSFETs $\mathrm{S}_{1}$ and $\mathrm{S}_{2}$ are simultaneously conducting, the two inductors $\mathrm{L}_{1}$ and $\mathrm{L}_{2}$ of the switchedinductor are charged in parallel by the input supply voltage Vin. The current direction is shown in Figure 3. Also, the two diodes $\mathrm{D}_{1}$ and $\mathrm{D}_{2}$ are reversed-biased, and therefore the two capacitors $\mathrm{C}_{1}$ and $\mathrm{C}_{2}$ get discharged in series. The load is supplied by the input voltage $\mathrm{V}_{\text {in }}$ and the discharged energy from the two capacitors $\mathrm{C}_{1}$ and $\mathrm{C}_{2}$.

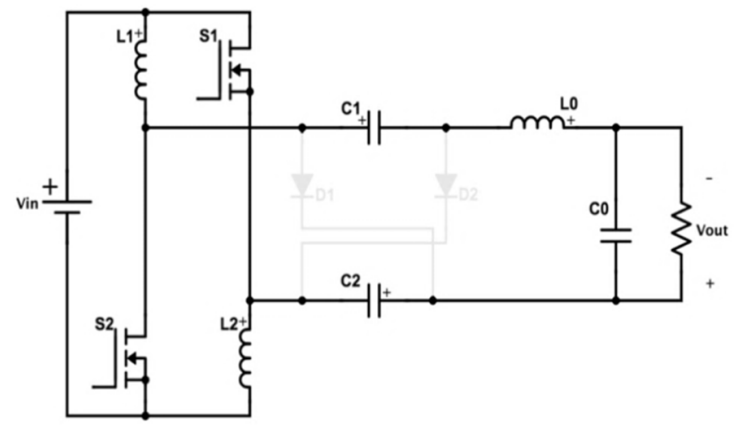

Fig. 3. The proposed Cuk converter in on-mode.

\section{B. Off-Mode}

When the two MOSFETs are simultaneously not conducting, the two inductors of the switched-inductor are discharged in series. The current direction is shown in Figure 4.

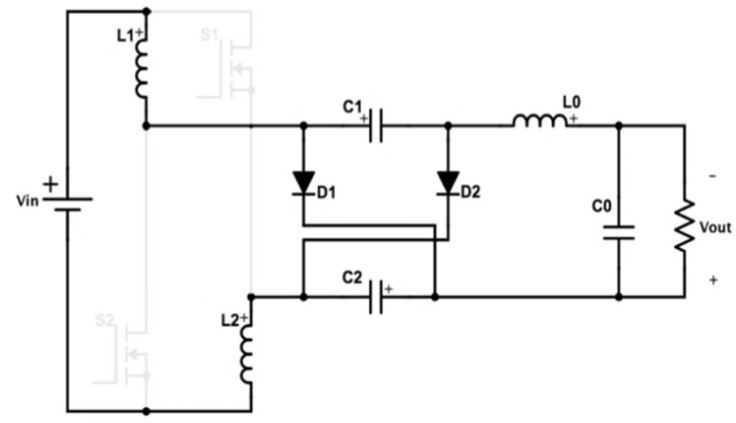

Fig. 4. Proposed Cuk converter in on-mode in off-mode.

Also, the two diodes are forward-biased, and therefore the two capacitors are charged in parallel. The load is supplied by the input voltage $V_{\text {in }}$ and the discharged energy from the two inductors. The switching diagram of the steady-state waveforms with enlarged variations in CCM of the proposed Cuk converter is shown in Figure 5.

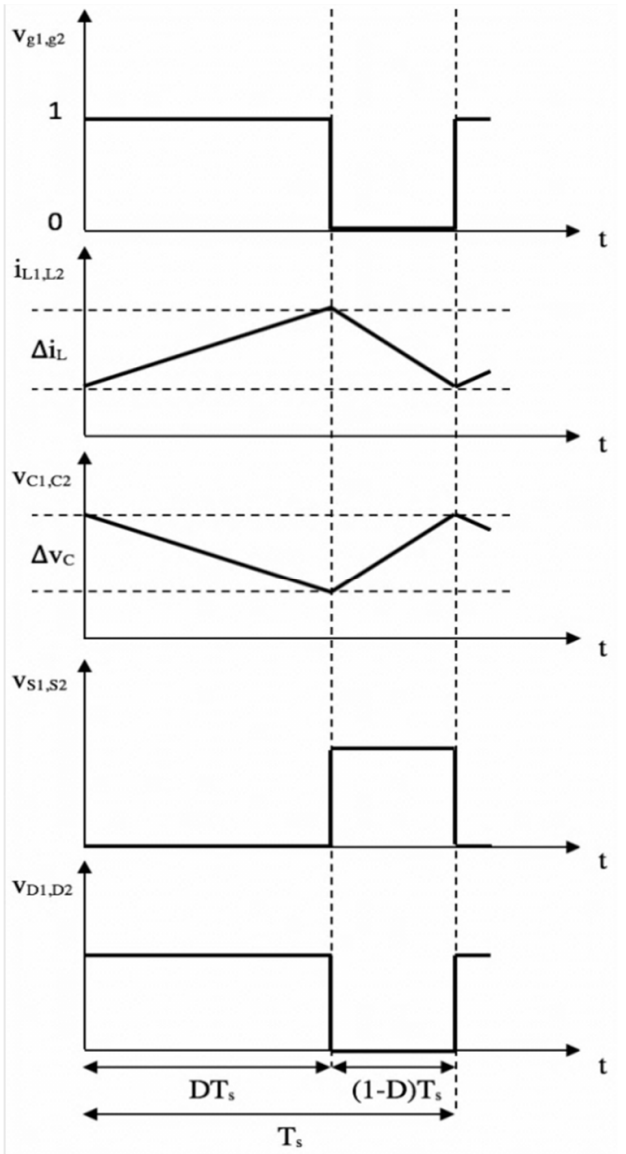

Fig. 5. Main steady-state waveforms of proposed Cuk converter.

\section{CIRCUIT ANALYSIS}

To simplify the analysis, it is assumed that the proposed Cuk converter is operating in steady-state. Likewise, the following assumptions are made: all components are ideal (100\% efficiency), the input voltage $\mathrm{V}_{\text {in }}$ is pure DC, and all capacitors $\mathrm{C}_{1}, \mathrm{C}_{2}$, and $\mathrm{C}_{\text {out }}$ are sized to have a relatively small voltage ripple at a switching frequency (f). When the two MOSFETs $S_{1}$ and $S_{2}$ are on, the voltage across the inductors $\mathrm{L}_{1}, \mathrm{~L}_{2}$, and $\mathrm{L}_{\text {out }}$ are expressed in (1) and (2) $\left(\mathrm{C}_{1}=\mathrm{C}_{2}=\mathrm{C}\right)$ :

$$
\begin{gathered}
\mathrm{V}_{\mathrm{L}_{1}}=\mathrm{V}_{\mathrm{L}_{2}}=\mathrm{V}_{\text {in }} \\
\mathrm{V}_{\mathrm{L}_{\text {out }}}=\mathrm{V}_{\text {in }}+2 \mathrm{~V}_{\mathrm{C}}-\mathrm{V}_{\text {out }}
\end{gathered}
$$

where $\mathrm{V}_{\mathrm{C}}$ stands for the voltage across capacitors $\mathrm{C}_{1}$ and $\mathrm{C}_{2}$.

When the two MOSFETs $S_{1}$ and $S_{2}$ are off, the voltages across the inductors $\mathrm{L}_{1}, \mathrm{~L}_{2}$, and $\mathrm{L}_{\text {out }}$ are expressed in (3) and (4):

$$
\begin{gathered}
V_{\mathrm{L}_{1}}=\mathrm{V}_{\mathrm{L}_{2}}=\frac{\mathrm{V}_{\text {in }}-\mathrm{V}_{\mathrm{C}}}{2} \\
\mathrm{~V}_{\mathrm{L}_{\text {out }}}=\mathrm{V}_{\mathrm{C}}-\mathrm{V}_{\text {out }}
\end{gathered}
$$


The expressions in (5) and (6) can be obtained by applying the volt-second method to the inductors $\mathrm{L}_{1}, \mathrm{~L}_{2}$, and $\mathrm{L}_{\text {out }}$ :

$$
\begin{gathered}
\mathrm{V}_{\text {in }} \mathrm{D}+\left(\frac{\mathrm{V}_{\text {in }}-\mathrm{V}_{\mathrm{C}}}{2}\right)(1-\mathrm{D})=0 \\
\left(\mathrm{~V}_{\text {in }}+2 \mathrm{~V}_{\mathrm{C}}-\mathrm{V}_{\text {out }}\right) \mathrm{D}+\left(\mathrm{V}_{\mathrm{C}}-\mathrm{V}_{\text {out }}\right)(1-\mathrm{D})=0
\end{gathered}
$$

From (5), the voltage across $C_{1}$ and $C_{2}$ is expressed in (7):

$$
\mathrm{V}_{\mathrm{C}}=\frac{(1+\mathrm{D})}{(1-\mathrm{D})} \mathrm{V}_{\text {in }}
$$

By substituting (7) into (6), the ideal voltage gain in CCM for the proposed Cuk converter is expressed in (8):

$$
\mathrm{M}_{\mathrm{CCM}}=\frac{\mathrm{V}_{\text {out }}}{\mathrm{V}_{\text {in }}}=\frac{\mathrm{I}_{\text {in }}}{\mathrm{I}_{\text {out }}}=\frac{(1+3 \mathrm{D})}{(1-\mathrm{D})}
$$

The output inductor average current $\mathrm{I}_{\mathrm{L}_{\text {out }}}$ can be considered equal to the output average current $\mathrm{I}_{\text {out }}$. Therefore, (9) is obtained from (8).

$$
\mathrm{I}_{\mathrm{L}_{\text {out }}}=\mathrm{I}_{\text {out }}=\frac{(1-\mathrm{D})}{(1+3 \mathrm{D})} \mathrm{I}_{\text {in }}
$$

Also, the input inductor currents can be obtained in (11) by using (10).

$$
\begin{gathered}
I_{\text {in }}=\left(2 I_{\text {in }}+I_{L_{\text {out }}}\right) D+I_{L}(1-D) \\
I_{L}=I_{L_{1}}=I_{L_{2}}=\frac{(1+D)}{(1+3 D)} I_{\text {in }}=\frac{(1+D) P_{\text {out }}}{(1+3 D) V_{\text {in }}}
\end{gathered}
$$

The voltage stress across the two diodes $D_{1}$ and $D_{2}$ are expressed in (12):

$$
\mathrm{V}_{\mathrm{D}_{1}}=\mathrm{V}_{\mathrm{D}_{2}}=\frac{2}{(1-\mathrm{D})} \mathrm{V}_{\mathrm{in}}
$$

The voltage stresses across the two MOSFETs are expressed in (13):

$$
\mathrm{V}_{\mathrm{S}_{1}}=\mathrm{V}_{\mathrm{S}_{2}}=\frac{1}{(1-\mathrm{D})} \mathrm{V}_{\text {in }}
$$

The peak-to-peak variation in input inductor's currents $\left(\Delta \mathrm{i}_{\mathrm{L}_{\mathrm{in}}}=\Delta \mathrm{i}_{\mathrm{L}_{1}}=\Delta \mathrm{i}_{\mathrm{L}_{2}}\right)$ is expressed in (14):

$$
\Delta \mathrm{i}_{\mathrm{L}_{\text {in }}}=\Delta \mathrm{i}_{\mathrm{L}_{1}}=\Delta \mathrm{i}_{\mathrm{L}_{2}}=\frac{\mathrm{DTV}_{\text {in }}}{\mathrm{L}_{\mathrm{in}}}=\frac{\mathrm{DV}_{\text {in }}}{\mathrm{fL}_{\text {in }}}
$$

The peak-to-peak variation in output inductor's current $\Delta \mathrm{i}_{\mathrm{L}_{\text {out }}}$ is expressed in (15)

$$
\Delta \mathrm{i}_{\mathrm{L}_{\text {out }}}=\frac{\mathrm{DT}\left(\mathrm{V}_{\text {in }}+2 \mathrm{~V}_{\mathrm{C}}-\mathrm{V}_{\text {out }}\right)}{\mathrm{L}_{\text {out }}}=\frac{\mathrm{D}\left(\mathrm{V}_{\text {in }}+2 \mathrm{~V}_{\mathrm{C}}-\mathrm{V}_{\text {out }}\right)}{\mathrm{fL}_{\text {out }}}
$$

The peak-to-peak variation in capacitor's voltage $\Delta \mathrm{v}_{\mathrm{C}}$ is expressed in (16).

$$
\Delta \mathrm{v}_{\mathrm{C}}=\frac{\mathrm{DTI}_{\text {out }}}{\mathrm{C}}=\frac{\mathrm{DP}_{\text {out }}}{\mathrm{M}_{\mathrm{CCM}} \mathrm{V}_{\text {in }} \mathrm{fC}}
$$

\section{CiRCUIT EXTENSIONS}

More switched-inductors can be attached to the proposed Cuk converter instead of the single inductors at the input side. This will lead to increase the voltage gain ratio even more. Also, to reduce the size of magnetic components, the inductors can be integrated into one magnetic core.

\section{A. Attaching More Switched-Inductors}

In order to increase the voltage gain even more, the single inductors at the input side of the proposed Cuk converter can be replaced with a switched-inductor. In this case, the voltage gain reaches above 23 when $\mathrm{D}=0.75$. The power circuit is shown in Figure 6. The voltage gain can be expressed as:

$$
\mathrm{M}_{\mathrm{CCM}}=\frac{\mathrm{v}_{\text {out }}}{\mathrm{v}_{\text {in }}}=\mathrm{D}+(1+\mathrm{D}) \frac{(1+3 \mathrm{D})}{(1-\mathrm{D})}
$$

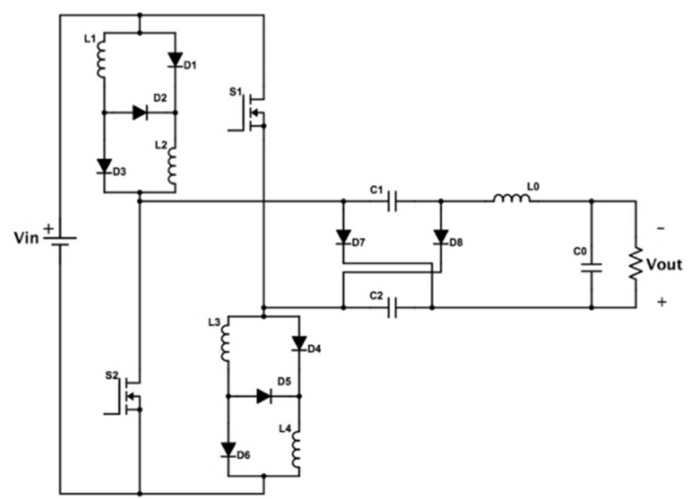

Fig. 6. More switched-inductors attached

\section{B. Coupled Inductors}

Actually, all the inductors presented in the last section share the same value of inductance and have the same operation condition. Therefore, to reduce the size of magnetic components, the inductors can be integrated into one magnetic core as shown in Figure 7.

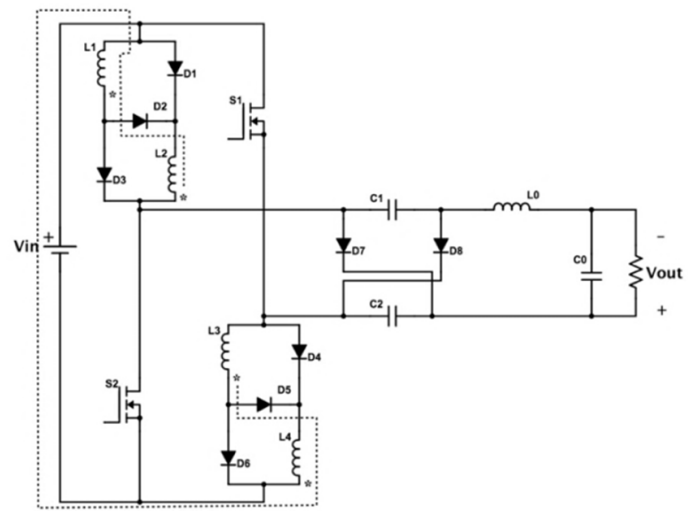

Fig. 7. Magnetic components integration.

\section{COMPARISON ANALYSIS}

In Table I, a comparison can be seen between the proposed Cuk converter, the single-switch Cuk converter [20], the hybrid switched-capacitor Cuk converter [21], the three-switch Cuk converter [22], and the conventional Cuk converter in terms of voltage gain, voltage stress, and number of components. The voltage gain and the voltage stress are graphically represented in Figures 8 and 9 respectively. As can be seen in Figure 8, the highest voltage gain can be accomplished by the proposed Cuk 
converter. However, the converter having the lowest voltage gain is the conventional Cuk converter. As can be seen in Figure 9, the converter having the highest voltage stress is the conventional Cuk converter. On the other hand, the lowest voltage stress can be maintained using the proposed Cuk converter. Therefore, the proposed Cuk converter is suitable for applications requiring higher voltage gain with lower voltage stress.

TABLE I. PROPOSED AND OTHER CUK CONVERTERS COMPARISON

\begin{tabular}{|c|c|c|c|c|c|}
\hline Cuk Converters & $\begin{array}{c}\text { Gain } \\
\left(\mathbf{M}_{\mathrm{CCM}}\right)\end{array}$ & $\begin{array}{c}\text { Switches } \\
\text { count }\end{array}$ & $\begin{array}{c}\text { Diodes } \\
\text { count }\end{array}$ & $\begin{array}{c}\text { Capacitors } \\
\text { count }\end{array}$ & $\begin{array}{c}\text { Inductors } \\
\text { count }\end{array}$ \\
\hline Proposed & $\frac{(1+3 \mathrm{D})}{(1-\mathrm{D})}$ & 2 & 2 & 3 & 2 \\
\hline Single-switch [20] & $\frac{2}{(1-\mathrm{D})}$ & 1 & 3 & 3 & 1 \\
\hline Hybrid SC [21] & $\frac{(1+\mathrm{D})}{(1-\mathrm{D})}$ & 1 & 2 & 3 & 2 \\
\hline Three-switch [22] & $\frac{1}{(1-\mathrm{D})}$ & 1 & 2 & 2 & 1 \\
\hline Conventional & $\frac{\mathrm{D}}{(1-\mathrm{D})}$ & 1 & 1 & 2 & 2 \\
\hline
\end{tabular}

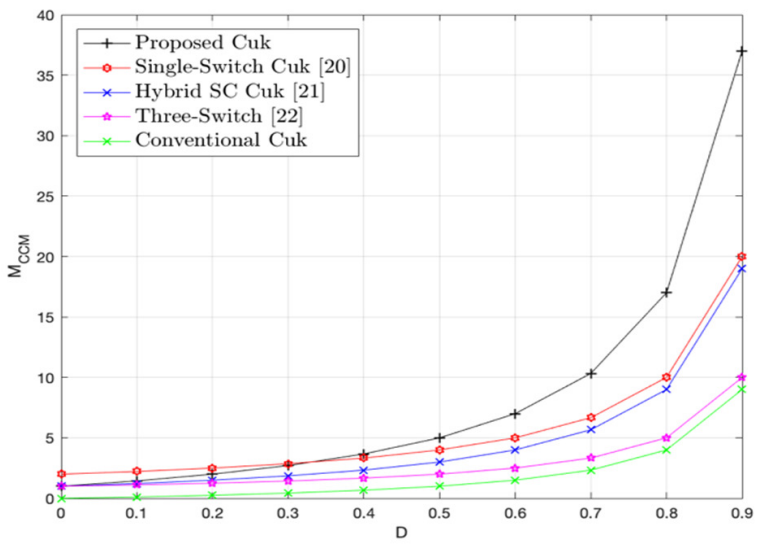

Fig. 8. Voltage gain comparison.

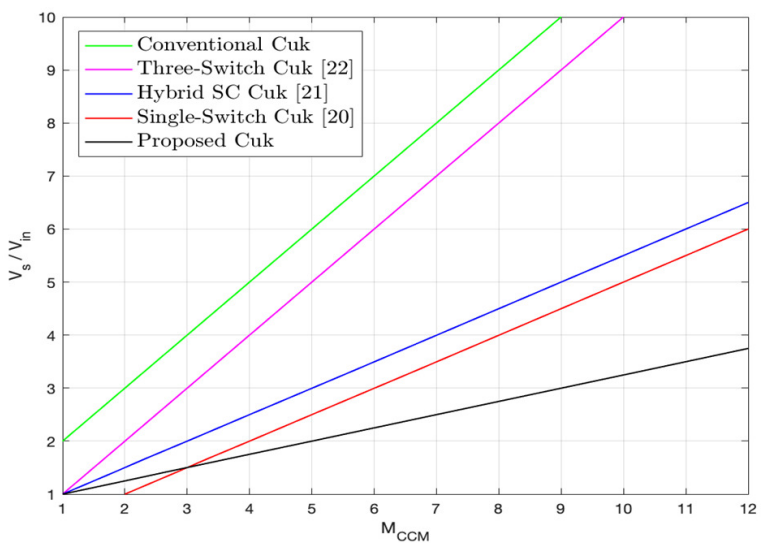

Fig. 9. Normalized voltage stress comparison on active switches.

\section{SIMULATION VERIFICATION AND DISCUSSION}

A prototype $12 /-152 \mathrm{~V}$ design is developed in Matlab/Simulink to verify the performance of the proposed Cuk converter. A Simulink prototype has been designed in Matlab as shown in Figure 10. The simulation specifications of the proposed Cuk converter are $12 \mathrm{~V}$ input voltage, $-152 \mathrm{~V}$ output voltage, $100 \mathrm{~W}$ rated power, $50 \mathrm{kHz}$ switching frequency, and $75 \%$ duty cycle. Detailed parameter values are shown in Table II. The voltage stress and current stress across the two MOSFETs $S_{1}$ and $S_{2}$ are $47 \mathrm{~V}$ and $5 \mathrm{~A}$ respectively. The voltage stress and current stress waveforms are shown in Figure 11. Figure 12 shows the voltage waveforms of diodes $D_{1}$ and $D_{2}$ which each one has a voltage stress of $-90 \mathrm{~V}$. Diodes $\mathrm{D}_{1}$ and $\mathrm{D}_{2}$ are reversed biased when the two MOSFETs $S_{1}$ and $S_{2}$ are on, and they are forward-biased when the two MOSFETs $S_{1}$ and $S_{2}$ are off. The voltage waveform of the two capacitors $C_{1}$ and $C_{2}$ is shown in Figure 13. The current waveforms of the three inductors $\mathrm{L}_{1}, \mathrm{~L}_{2}$, and $\mathrm{L}_{\text {out }}$ are shown in Figure 14.

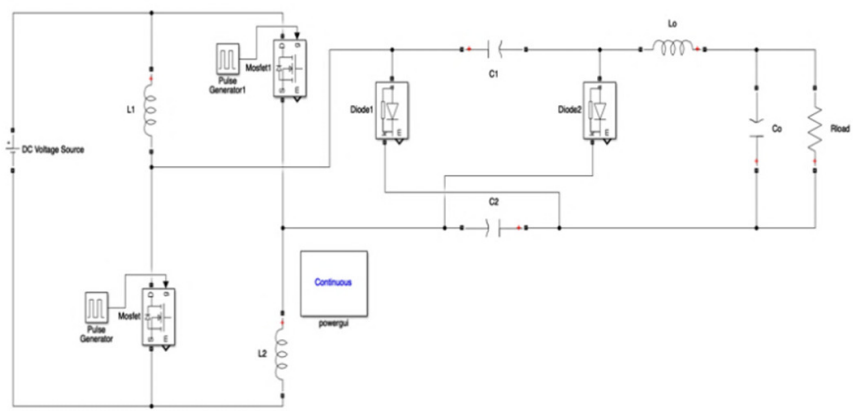

Fig. 10. Simulink model of the proposed Cuk converter.

TABLE II. DESIGN SPECIFICATIONS OF THE PROPOSED CUK CONVERTER

\begin{tabular}{|c|c|}
\hline Parameter & Value \\
\hline Input voltage $\left(\mathrm{V}_{\text {in }}\right)$ & $12 \mathrm{~V}$ \\
\hline Output voltage $\left(\mathrm{V}_{\text {out }}\right)$ & $-152 \mathrm{~V}$ \\
\hline Rated power $\left(\mathrm{P}_{\text {out }}\right)$ & $100 \mathrm{~W}$ \\
\hline Switching frequency $(\mathrm{f})$ & $50 \mathrm{kHz}$ \\
\hline Duty cycle $(\mathrm{D})$ & $75 \%$ \\
\hline Inductors $\left(\mathrm{L}_{1}, \mathrm{~L}_{2}\right.$, and $\left.\mathrm{L}_{\text {out }}\right)$ & $600 \mu \mathrm{H}$ \\
\hline Capacitors $\left(\mathrm{C}_{1}\right.$ and $\left.\mathrm{C}_{2}\right)$ & $22 \mu \mathrm{F}$ \\
\hline Load $\left(\mathrm{R}_{\text {Load }}\right)$ & $230 \Omega$ \\
\hline
\end{tabular}
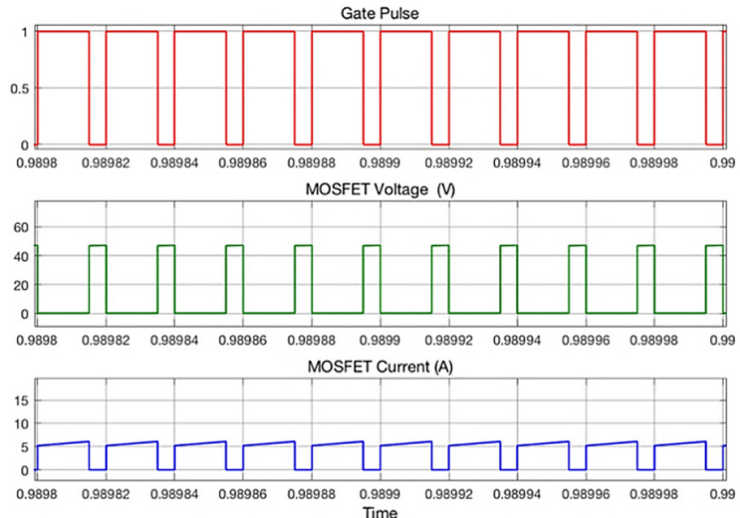

Fig. 11. Voltage and current waveforms across MOSFETs $\mathrm{S}_{1}$ and $\mathrm{S}_{2}$ 

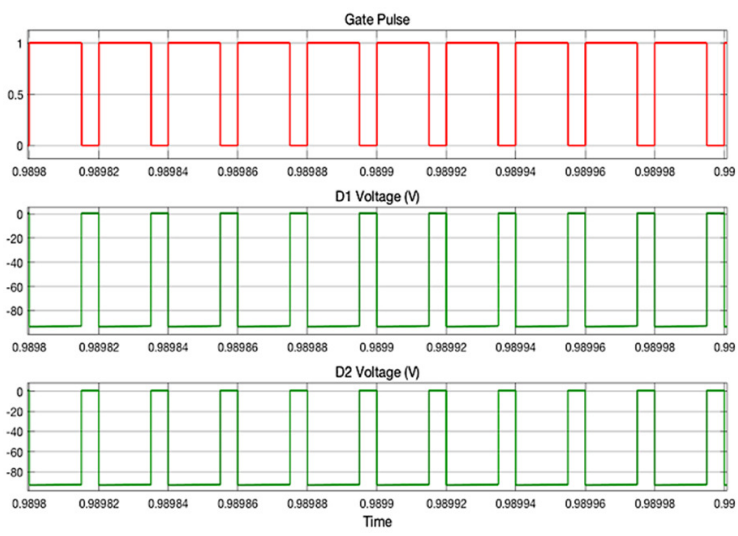

Fig. 12. Voltage waveform across diodes $\mathrm{D}_{1}$ and $\mathrm{D}_{2}$.
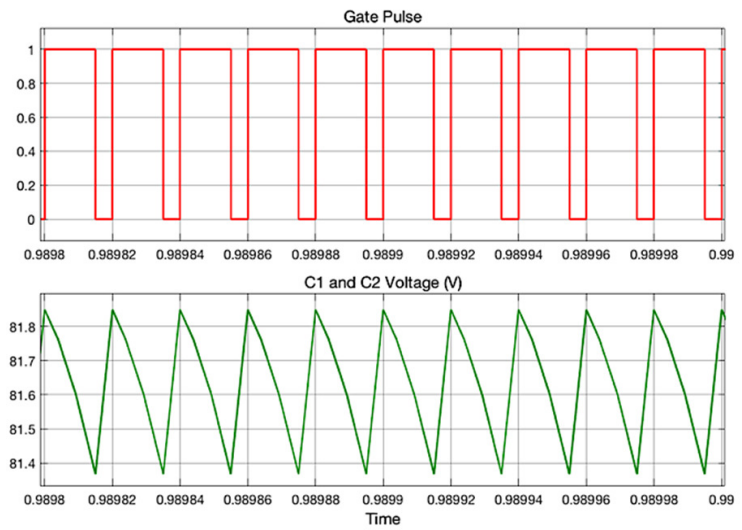

Fig. 13. Voltage waveform across capacitors $\mathrm{C}_{1}$ and $\mathrm{C}_{2}$.
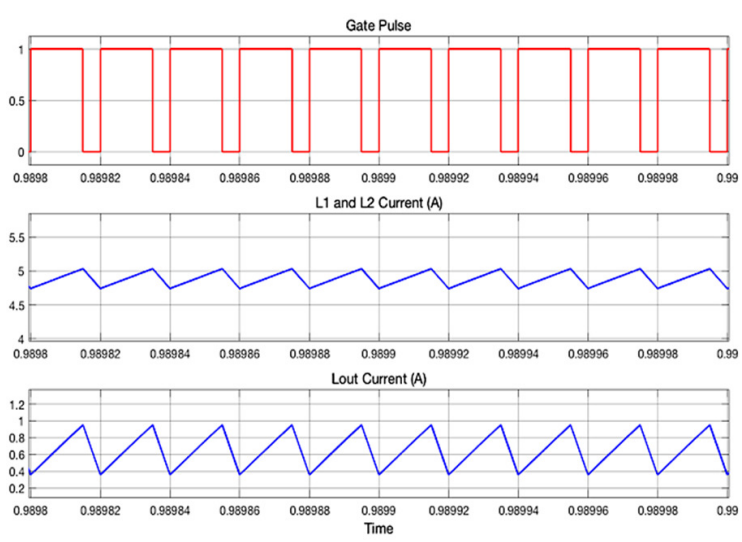

Fig. 14. Current waveforms across inductors $\mathrm{L}_{1}$ and $\mathrm{L}_{2}$.

Finally, the input voltage $\mathrm{V}_{\text {in }}(12 \mathrm{~V})$, the output voltage $\mathrm{V}_{\text {out }}(-152 \mathrm{~V})$, and the output power $\mathrm{P}_{\text {out }}(100 \mathrm{~W})$ waveforms are shown in Figure 15. The efficiency of the proposed Cuk converter is calculated as the output power increase as shown in Figure 16. The highest efficiency is $92 \%$ when the output power is $180 \mathrm{~W}$. When the input voltage is increased, the efficiency of the proposed Cuk converter is increased because the input current decreases, and therefore, the conduction losses on switches get reduced.
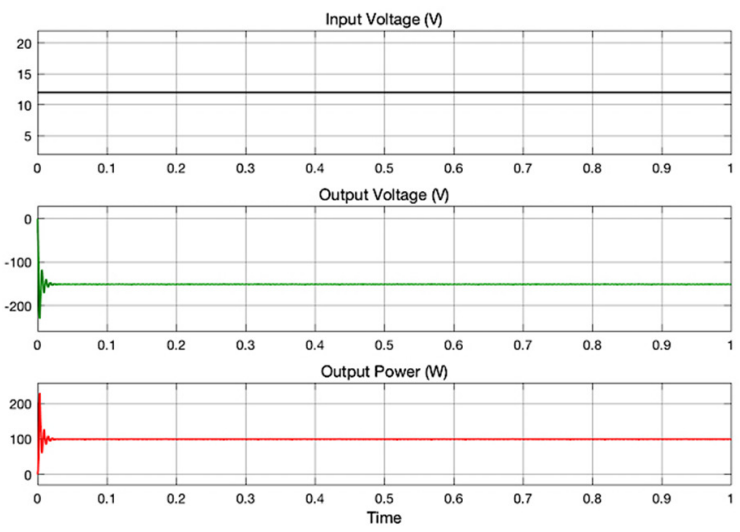

Fig. 15. Waveforms of $\mathrm{V}_{\mathrm{in}}, \mathrm{V}_{\text {out }}$, and $\mathrm{P}_{\text {out }}$.

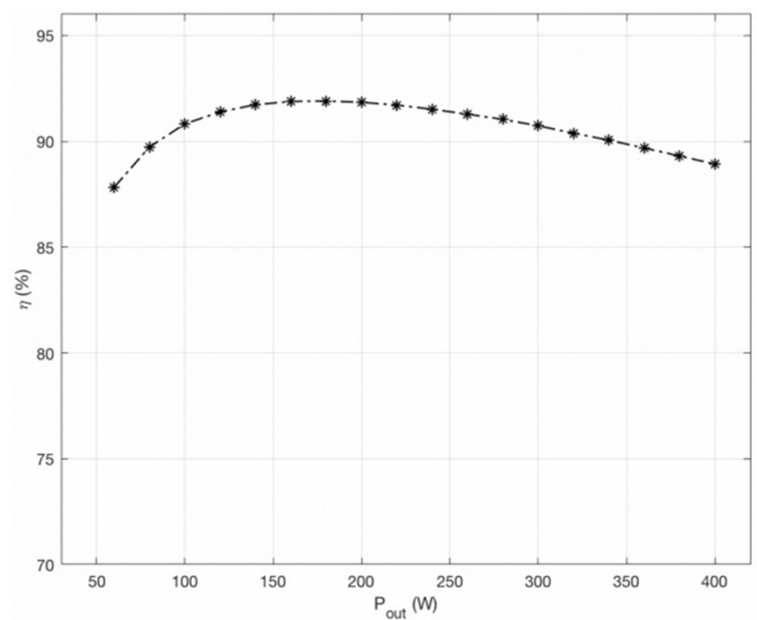

Fig. 16. Efficiency curve as a function of the output power.

\section{CONCLUSION}

A two-switch high gain non-isolated Cuk converter was presented in this paper. The proposed Cuk converter is useful in renewable energy applications, such as PV and fuel cell, that require high voltage gain with reduced voltage stress on semiconductor switches. The reduced voltage stress on semiconductor switches will lead to have lower $\mathrm{R}_{\mathrm{DS}-\mathrm{ON}}$, and therefore, higher efficiency. A higher voltage gain is achieved when the single inductor and capacitor in the conventional Cuk converter are replaced with a switched-inductor and switchedcapacitor respectively. Theoretically, the proposed Cuk converter is able to achieve 13 times the input voltage when the duty cycle (D) is 0.75 . The steady-state analysis is verified by constricting a $12 /-152 \mathrm{~V}$ prototype Cuk converter in Matlab/Simulink.

\section{REFERENCES}

[1] M. Hussain, M. H. Baloch, A. H. Memon, and N. K. Pathan, "Maximum Power Tracking System Based on Power Electronic Topology for Wind Energy Conversion System Applications," Engineering, Technology \& Applied Science Research, vol. 8, no. 5, pp. 3392-3397, Oct. 2018.

[2] Z. R. Labidi, H. Schulte, and A. Mami, "A Systematic Controller Design for a Photovoltaic Generator with Boost Converter Using Integral State Feedback Control," Engineering, Technology \& Applied Science Research, vol. 9, no. 2, pp. 4030-4036, Apr. 2019. 
[3] D. López del Moral, A. Barrado, M. Sanz, A. Lázaro, and P. Zumel, "Analysis and implementation of the Buck-Boost Modified Series Forward converter applied to photovoltaic systems," Solar Energy, vol. 176, pp. 771-787, Dec. 2018, doi: 10.1016/j. solener.2018.10.053.

[4] M. Kasper, D. Bortis, and J. W. Kolar, "Classification and Comparative Evaluation of PV Panel-Integrated DC-DC Converter Concepts," IEEE Transactions on Power Electronics, vol. 29, no. 5, pp. 2511-2526, May 2014, doi: 10.1109/TPEL.2013.2273399.

[5] O. Deveci and C. Kasnakoğlu, "Performance improvement of a photovoltaic system using a controller redesign based on numerical modeling," International Journal of Hydrogen Energy, vol. 41, no. 29, pp. 12634-12649, Aug. 2016, doi: 10.1016/j.ijhydene.2016.05.149.

[6] K.-C. Tseng, C.-C. Huang, and C.-A. Cheng, "A High Step-Up Converter With Voltage-Multiplier Modules for Sustainable Energy Applications," IEEE Journal of Emerging and Selected Topics in Power Electronics, vol. 3, no. 4, pp. 1100-1108, Dec. 2015, doi: 10.1109/ JESTPE.2015.2404943.

[7] X. Zhu, B. Zhang, Z. Li, H. Li, and L. Ran, "Extended Switched-Boost DC-DC Converters Adopting Switched-Capacitor/Switched-Inductor Cells for High Step-up Conversion," IEEE Journal of Emerging and Selected Topics in Power Electronics, vol. 5, no. 3, pp. 1020-1030, Sep. 2017, doi: 10.1109/JESTPE.2016.2641928.

[8] E. H. Ismail, M. A. Al-Saffar, and A. J. Sabzali, "High Conversion Ratio DC-DC Converters With Reduced Switch Stress," IEEE Transactions on Circuits and Systems I: Regular Papers, vol. 55, no. 7, pp. 21392151, Aug. 2008, doi: 10.1109/TCSI.2008.918195.

[9] Y. Almalaq, A. Alateeq, and M. Matin, "A Transformerless High Gain Switched-Inductor Switched-Capacitor Cuk Converter in Step-Up Mode," in 2018 IEEE International Conference on Electro/Information Technology (EIT), May 2018, pp. 0138-0141, doi: 10.1109/EIT.2018. 8500104.

[10] W. Li, X. Lv, Y. Deng, J. Liu, and X. He, "A Review of Non-Isolated High Step-Up DC/DC Converters in Renewable Energy Applications," in 2009 Twenty-Fourth Annual IEEE Applied Power Electronics Conference and Exposition, Feb. 2009, pp. 364-369, doi: 10.1109/ APEC.2009.4802683.

[11] C.-T. Pan and C.-M. Lai, "A High-Efficiency High Step-Up Converter With Low Switch Voltage Stress for Fuel-Cell System Applications," IEEE Transactions on Industrial Electronics, vol. 57, no. 6, pp. 19982006, Jun. 2010, doi: 10.1109/TIE.2009.2024100.

[12] M. Gokdag, M. Akbaba, and O. Gulbudak, "Switched-capacitor converter for PV modules under partial shading and mismatch conditions," Solar Energy, vol. 170, pp. 723-731, Aug. 2018, doi: 10.1016/j.solener.2018.06.010.

[13] K.-C. Tseng, C.-C. Huang, and W.-Y. Shih, "A High Step-Up Converter With a Voltage Multiplier Module for a Photovoltaic System," IEEE Transactions on Power Electronics, vol. 28, no. 6, pp. 3047-3057, Jun. 2013, doi: 10.1109/TPEL.2012.2217157.

[14] Y.-P. Hsieh, J.-F. Chen, T.-J. P. Liang, and L.-S. Yang, "Novel High Step-Up DC-DC Converter With Coupled-Inductor and SwitchedCapacitor Techniques for a Sustainable Energy System," IEEE Transactions on Power Electronics, vol. 26, no. 12, pp. 3481-3490, Dec. 2011, doi: 10.1109/TPEL.2011.2160876.

[15] Y.-P. Hsieh, J.-F. Chen, T.-J. Liang, and L.-S. Yang, "A Novel High Step-Up DC-DC Converter for a Microgrid System," IEEE Transactions on Power Electronics, vol. 26, no. 4, pp. 1127-1136, Apr. 2011, doi: 10.1109/TPEL.2010.2096826.

[16] S.-K. Changchien, T.-J. Liang, J.-F. Chen, and L.-S. Yang, "Novel High Step-Up DC-DC Converter for Fuel Cell Energy Conversion System," IEEE Transactions on Industrial Electronics, vol. 57, no. 6, pp. 20072017, Jun. 2010, doi: 10.1109/TIE.2009.2026364.

[17] Y. Almalaq and M. Matin, "Three Topologies of a Non-Isolated High Gain Switched-Inductor Switched-Capacitor Step-Up Cuk Converter for Renewable Energy Applications," Electronics, vol. 7, no. 6, p. 94, Jun. 2018, doi: 10.3390/electronics7060094.

[18] S. Cuk and R. D. Middlebrook, "A general unified approach to modelling switching DC-tO-DC converters in discontinuous conduction mode," in 1977 IEEE Power Electronics Specialists Conference, Jun. 1977, pp. 36-57, doi: 10.1109/PESC.1977.7070802.
[19] S. Chincholkar and C.-Y. Chan, "Design and implementation of an output feedback controller for the Cuk converter," in IECON 2015 - 41st Annual Conference of the IEEE Industrial Electronics Society, Nov. 2015, pp. 86-90, doi: 10.1109/IECON.2015.7392080.

[20] E. H. Ismail, M. A. Al-Saffar, A. J. Sabzali, and A. A. Fardoun, “A Family of Single-Switch PWM Converters With High Step-Up Conversion Ratio," IEEE Transactions on Circuits and Systems I: Regular Papers, vol. 55, no. 4, pp. 1159-1171, May 2008, doi: 10.1109/ TCSI.2008.916427.

[21] B. Axelrod, Y. Berkovich, and A. Ioinovici, "Hybrid switched-capacitorCuk/Zeta/Sepic converters in step-up mode," in 2005 IEEE International Symposium on Circuits and Systems, May 2005, pp. 1310-1313 Vol. 2 , doi: 10.1109/ISCAS.2005.1464836.

[22] Dongyan Zhou, A. Pietkiewicz, and S. Cuk, "A three-switch highvoltage converter," IEEE Transactions on Power Electronics, vol. 14, no. 1, pp. 177-183, Jan. 1999, doi: 10.1109/63.737606. 